\title{
PERAN TEKNOLOGI PEMBELAJARAN ISLAM DALAM ORGANISASI BELAJAR
}

\section{Elihami*}

Email: elihamid@ymail.com

STKIP Muhammadiyah Enrekang

\section{Andi Saharuddin**}

STKIP Muhammadiyah Enrekang

\begin{tabular}{ll}
\hline Keyword & Abstrak \\
\hline $\begin{array}{l}\text { Teknologi } \\
\text { pembelajaran } \\
\text { islami, organisasi }\end{array}$ & $\begin{array}{l}\text { Teknologi pembelajaran islam meliputi desain, pengembangan, } \\
\text { pemanfaatan, pengelolaan, penilaian dan penelitian proses, sumber } \\
\text { dan sistem untuk belajar sesuai yang terkandung dalam Alqur'an dan } \\
\end{array}$ \\
& Hadist. Definisi dan kawasan teknologi pembelajaran Islam ini \\
& merupakan kajian teori. Adapun peran teknologi pembelajaran Islam \\
& dalam pemecahan masalah-masalah pembelajaran ini merupakan \\
kajian praktis dan terapan. Artinya berkaitan dengan pemanfaatan & teknologi pembelajaran Islam dalam memfasilitasi organisasi belajar \\
& manusia. Akhirnya teknologi pembelajaran Islam baik sebagai disiplin \\
& ilmu, program studi maupun profesi terus mengalami perkembangan \\
& yang pesat.
\end{tabular}

\section{PENDAHULUAN}

Peran utama teknologi pembelajaran islam yakni memecahkan masalah belajar atau memfasilitasi kegiatan pembelajaran dalam kajian keislaman. Teknologi pembelajaran islam sebagai perangkat lunak (sofware technology) yang berbentuk cara-cara yang sistematis dalam memecahkan masalah pembelajaran semakin canggih dan mendapat tempat secara luas dalam dunia pendidikan ${ }^{1}$. Dengan demikian aplikasi

\footnotetext{
${ }^{1}$ Suparman, M. Atwi \& Zuhairi, Aminudin (2004), "Pendidikan Jarak Jauh Teori dan
}

praktis teknologi pembelajaran islam dalam pemecahan masalah belajar mempunyai bentuk nyata dengan adanya sumber belajar yang memfasilitasi peserta didik dalam organisasi belajar.

Teknologi pembelajaran Islam tumbuh dan berkembang dari praktek pendidikan dan gerakan komunikasi audio visual. Teknologi pembelajaran islam semula dilihat sebagai teknologi peralatan, yang berkaitan dengan penggunaan peralatan, media dan sarana untuk mencapai tujuan pendidikan atau

Praktek", (Jakarta: Pusat Penerbitan universitas Terbuka), hal. 345-346. 
kegiatan pembelajaran dengan memanfaatkan alat bantu audiovisual ${ }^{2}$.Teknologi pembelajaran islam merupakan gabungan dari tiga aliran yang saling berkepentingan, yaitu media pendidikan, psikologi pembelajaran dan pendekatan sistem untuk pendidikan ${ }^{3}$.

Dalam perkembangan selanjutnya teknologi pembelajaran islam menggunakan tiga prinsip dasar yang perlu dijadikan acuan dalam pengembangan dan pemanfaatannya, yaitu: 1). pendekatan sistem (system approach), 2). berorientasi pada peserta didik (learner centered), dan 3). pemanfaatan sumber belajar semaksimal dan sebervariasi mungkin (utilizing learning resources $)^{4}$. Prinsip pendekatan sistem berarti bahwa setiap usaha pemecahan masalah pendidikan yang dilandasi konsep teknologi pembelajaran islam hendaknya menerapkan prinsip pendekatan sistem. Artinya memandang segala sesuatu sebagai sesuatu yang meneluruh (komprehensif) dengan segala komponen yang saling terintegrasi. Prisip berorientasi pada peserta didik, berarti bahwa usaha-usaha pendidikan, pembelajaran dan pelatihan hendaknya memusatkan perhatiannya pada peserta didik. Sedangkan prinsip ketiga yaitu pemanfaatan sumber organisasi belajar berarti peserta didik belajar karena berinteraksi dengan berbagai sumber belajar secara maksimal dan bervariasi.Pemikiran tentang Kerucut pengalaman (Cone of experience) ini merupakan upaya awal untuk memberikan alasan atau dasar tentang keterkaitan antara teori belajar dengan komunikasi audio visual ${ }^{5}$. Kerucut

2 Lihat Rountree (2004). Instructional technology and media for learning. ( $8^{\text {th }}$ ed.). (Englewood Cliffs, N.J.: Prentice Hall.

3 Lihat Seels, Barbara B. \& Richey, Rita C., (2000), Instructional technology, The definition and domains of the field, Terjemahan Dewi S Prawiradilaga, R. Rahardjo, Yusufhadi Miarso, (Jakarta: Penerbit IPTPI \& LPTK).

${ }^{4}$ Ibid hal. 10

5 Lihat Dale, Planning, producing and using instructional technologies $\left(7^{\text {th }}\right.$ ed.), (New York: Harper Collins). pengalaman telah menyatukan teori pendidikan dengan gagasan- gagasan dalam bidang psikologi yang tengah populer pada masa itu.

Dalam rangka pembangunan ekonomi peran teknologi pembelajaran islam perlu berkelanjutan, hal yang dianggap sebagai suatu yang menjadi prioritas yakni Tenaga kerja yang diperlu-kan dalam era perubahan ini. Perlunya pengembangan Sumber Daya Manusia yang terdidik dengan baik, ter-latih dengan baik dan menguasai infor-masi (well educated, well trained, and well informed).

Dalam mengusulkan bidang komunikasi audio-visual menjadi teknologi pembelajaran islam yang belum berkembang hingga saat ini menjadi suatu profesi tersendiri, dengan didukung oleh penelitian, teori dan teknik tersendiri. Mengenai terintegrasinya sistem dan proses mampu mencakup dan memperluas gagasan tentang keterkaitan antara bahan belajar dengan proses pembelajaran. Dengan kata lain pemanfaatan media dalam kegiatan pembelajaran ${ }^{6}$.

\section{PEMBAHASAN}

Teknologi pembelajaran islam a dalah teori dan praktek dalam desain, pengembangan, pemanfaatan, pengelolaan, serta evaluasi tentang proses dan sumber untuk belajar ${ }^{7}$. Teknologi pembelajaran islam telah mengalami beberapa perubahan, sejalan dengan sejarah dan perkembangan dari teknologi pembelajaran islam itu sendiri. Di bawah ini dikemukakan beberapa definisi tentang teknologi pembelajaran islam yang memiliki pengaruh terhadap perkembangan teknologi pembelajaran.

Association for Educational Communications Technology (AECT, 1963) atau Asosiasi Komunikasi dan Teknologi Pendidikan). "Komunikasi audio-visual adalah cabang dari teori dan praktek pendidikan yang terutama berkepentingan dengan mendesain, dan menggunakan pesan

\footnotetext{
${ }^{6}$ Finn, J. D. (1960). Technology and the instructional process, Audiovisual Communication Review, 8(1), hal. 9-10.

${ }^{7}$ Lihat Seels \& Richey, hal.10.
} 
untuk mengendalikan proses belajar, mencakup kegiatan: (a) mempelajari kelemahan dan kelebihan suatu pesan dalam proses belajar; (b) penstrukturan dan sistematisasi oleh orang maupun instrumen dalam lingkungan pendidikan, meliputi: perencanaan, produksi, pemilihan, manajemen dan pemanfaatan dari komponen maupun keseluruhan sistem pembelajaran. Tujuan praktisnya adalah pemanfaatan setiap metode dan media komunikasi secara efektif untuk membantu pengembangan potensi peserta didik secara maksimal" ${ }^{8}$ Definisi di atas masih menggunakan istilah komunikasi audio-visual, namun telah menghasilkan kerangka dasar bagi pengembangan teknologi pembelajaran islamberikutnya serta dapat mendorong terjadinya peningkatan kualitas dan efisiensi pembelajaran.

Teknologi pembelajaran islam diartikan sebagai media yang lahir sebagai akibat revolusi komunikasi yang dapat digunakan untuk keperluan pembelajaran di samping guru, buku teks, dan papan tulis merupakan bagian yang membentuk teknologi pembelajaran islam adalah televisi, film, OHP, komputer dan bagian perangkat keras maupun lunak lainnya. Teknologi pembelajaran Islam merupakan usaha sistematik dalam merancang, melaksanakan, dan mengevaluasi keseluruhan proses belajar untuk suatu tujuan pembelajaran khusus, serta didasarkan pada penelitian tentang proses belajar dan komunikasi pada manusia yang menggunakan kombinasi sumber manusia dan non manusia agar belajar dapat berlangsung efektif."

Dengan mencantumkan istilah tujuan pembelajaran khusus, tampaknya rumusan tersebut berusaha mengakomodir pengaruh pemikiran B.F. Skinner (salah seorang tokoh Psikologi Behaviorisme) dalam teknologi pembelajaran. Begitu juga, rumusan tersebut memandang pentingnya penelitian tentang metode dan teknik yang digunakan untuk mencapai tujuan pembelajaran khusus.
Teknologi pembelajaran islam sebagai pengembangan (riset, desain, produksi, evaluasi, dukungan-pasokan, pemanfaatan) komponen sistem pembelajaran (pesan, orang, bahan, peralatan, teknik dan latar) serta pengelolaan usaha pengembangan (organisasi dan personal) secara sistematik, dengan tujuan untuk memecahkan masalah belajar".Adapun definisi yang dikemukakan oleh Kenneth Silber di atas menyebutkan istilah pengembangan. Pada definisi sebelumnya yang dimaksud dengan pengembangan lebih diartikan pada pengembangan potensi manusia. Dalam definisi Silber, penggunaan istilah pengembangan memuat dua pengertian, disamping berkaitan dengan pengembangan potensi manusia juga diartikan pula sebagai pengembangan dari teknologi pembelajaran islamitu sendiri, yang mencakup: perancangan, produksi, penggunaan atau pemanfaatan dan penilaian teknologi untuk pembelajaran. Selanjutnya, definisi MacKenzie dan Eraut 1971: "Teknologi pendidikan islammerupakan suatu studi yang sistematik mengenai cara bagaimana tujuan pendidikan dapat dicapai" Definisi sebelumnya meliputi istilah, "mesin", instrumen" atau "media", sedangkan dalam definisi ini tidak menyebutkan perangkat lunak maupun perangkat keras, tetapi lebih berorientasi pada proses dalam mencapai tujuan.

Definisi AECT 1972, pada tahun 1972, AECT berupaya merevisi defisini yang sudah ada (1963, 1970, 1971), dengan memberikan rumusan sebagai berikut : "Teknologi pendidikan islamadalah suatu bidang garapan yang berkepentingan dengan memfasilitasi belajar pada manusia melalui usaha sistematik dalam: identifikasi, pengembangan, pengorganisasian dan pemanfaatan berbagai macam sumber belajar serta dengan pengelolaan atas keseluruhan proses tersebut".Definisi ini didasari semangat untuk menetapkan komunikasi audio-visual sebagai suatu bidang studi. Ketentuan ini mengembangkan gagasan bahwa teknologi pendidikan islammerupakan suatu profesi. "Teknologi 
pendidikan islamadalah suatu proses yang kompleks dan terintegrasi meliputi orang, prosedur, gagasan, sarana, dan organisasi untuk menganalisis masalah, merancang, melaksanakan, menilai dan mengelola pemecahan masalah dalam segala aspek belajar pada manusia.

Definisi tahun 1977, AECT berusaha mengidentifikasi teknologi pendidikan islamsebagai suatu teori, bidang garapan dan profesi. Definisi sebelumnya, kecuali pada tahun 1963, tidak menekankan teknologi pendidikan islamsebagai suatu teori. Namun dalam definisi AECT 1994 yakni “ Instructional technology is the theory and practice of design, development, utilization, management and evaluation of processes and resources for learning,". Teknologi pembelajaran islamadalah teori dan praktek dalam desain, pengembangan, pemanfaatan, pengelolaan, serta evaluasi tentang proses dan sumber untuk belajar.

Meski dirumuskan dalam kalimat yang lebih sederhana, definisi ini sesungguhnya mengandung pengertian yang mendalam. Definisi ini berupaya semakin memperkokoh teknologi pembelajaran islamsebagai suatu bidang garapan dan profesi, yang perlu didukung oleh landasan teori dan praktek. Definisi ini juga berusaha menyempurnakan wilayah atau kawasan bidang kegiatan teknologi pembelajaran islammelalui kajian terori dan penelitian. Di samping itu, definisi ini berusaha menekankan pentingnya proses dan produk.

Definisi menurut Anglin 1995 yakni "Teknologi pendidikan islam adalah kombinasi dari pembelajaran, belajar, pengembangan, pengelolaan, dan teknologi lain yang diterapkan untuk memecahkan masalah pendidikan." ${ }^{10}$ Definisi ini memandang teknologi pendidikan islamsebagai salah satu cabang dari disiplin ilmu pendidikan yang berkembang sejalan dengan perkembangan teknologi. Sejak

\footnotetext{
${ }^{9}$ Lihat Seels dan Richey, hal. 1

${ }^{10}$ Anglin, Gary J. (1995), Instructional Technology, Past, Present, and Future, Second Edition, (Englewood-Corolado. Libraries unlimited, INC), hal.8.
}

dimasukkannya unsur teknologi ke dalam kajian dan praktek pendidikan, semenjak itulah lahir disiplin teknologi pendidikan ${ }^{11}$.

Definisi menurut Hackbarth 1996 menurut" Teknologi pendidikan islamadalah konsep multidemensional yang meliputi: 1) suatu proses sistematis yang melibatkan penerapan pengetahuan dalam upaya mencari solusi yang dapat digunakan dalam memecahkan masalah-masalah belajar dan pembelajaran, 2) produk seperti buku teks, program audio, program televisi, software komputer, dan lain-lain, 3) suatu profesi yang terdiri dari berbagai kategori pekerjaan, dan 4) merupakan bagian spesifik dari pendidikan." 12

Berdasarkan definisi ini teknologi pendidikan islammempunyai dua bidang kajian utama, yaitu: a). mengkaji tentang teori belajar dan perilaku manusia lainnya (soft technology), dan b) mengkaji teknologi terapan yang diaplikasikan untuk memecahkan masalah pembelajaran (hard technology). Namun, fokus dari teknologi pembelajaran islambukan pada proses psikologis bagaimana peserta didik belajar, melainkan pada proses bagaimana teknologi perangkat lunak dan keras digunakan mengkomunikasikan pengetahuan, keterampilan, atau sikap kepada peserta didik sehingga peserta didik mengalami perubahan perilaku seperti yang diharapkan ${ }^{13}$.

Definisi menurut AECT (2004): "Educational technology is the study and ethical practice of facilitating learning and improving performance by creating, using, and managing appropriate technological processes and resources" 14. Definisi terbaru teknologi pendidikan islamadalah studi dan etika praktek dalam

\begin{tabular}{l}
\hline${ }^{11}$ Ibid \\
${ }^{12}$ Hackbarth, Steven, (1996), The \\
Educational Technology Handbook, A \\
Comprehensive Guide: Process and Product for \\
Learning, (Englewood Cliffs: Educational \\
Technology Publications). \\
${ }_{13}$ Suparman, M. Atwi (2004), "Desain \\
Instruksional”, (Jakarta: Pusat Penerbitan \\
universitas Terbuka),hal. 30-31. \\
Lihat (AECT, 2004)
\end{tabular}


upaya memfasilitasi pembelajaran dan meningkatkan kinerja dengan cara menciptakan, menggunakan atau memanfaatkan dan mengelola proses dan sumber-sumber teknologi yang tepat. Dengan demikian tujuannya masih tetap untuk memfasilitasi pembelajaran agar lebih efektif, efisien dan menyenangkan serta meningkatkan kinerja.

Berdasarkan definisi-definisi diatas dapat disimpulkan bahwa:1) teknologi pembelajaran islamadalah suatu disiplin ilmu atau bidang gaapan 2). istilah teknologi pembelajaran islamdipakai bergantian dengan istilah teknologi pendidikan, 3). tujuan utama teknologi pembelajaran islamadalah (a) untuk memecahkan masalah belajar atau memfasilitasi pembelajaran; dan (b) untuk meningkatkan kinerja; 4). menggunakan pendekatan sistemik (holistik atau menyeluruh); 5). kawasan teknologi pembelajaran islamdapat meliputi kegiatan yang berkaitan dengan analisis, desain, pengembangan, pemanfaatan, pengelolaan, implementasi dan evaluasi baik prosesproses maupun sumber-sumber belajar, 6). teknologi pembelajaran islamtidak hanya bergerak di persekolahan tapi juga dalam semua aktifitas manusia (seperti perusahaan, keluarga, organisasi masyarakat, dan lain lain) sejauh berkaitan dengan upaya memecahkan masalah belajar dan peningkatan kinerja, 7). teknologi diartikan secara luas, bukan hanya teknologi fisik (hardtech), tapi juga teknologi lunak (softtech)

Dengan demikian beberapa definisi teknologi pembelajaran islamdi atas, tampaknya dari waktu ke waktu teknologi pemebelajaran mengalami proses "metamorfosa" menuju penyempurnaan. Teknologi pemebelajaran islam pada awalnya hanya dipandang sebagai alat berubah ke sistem yang lebih luas, dari hanya berorientasi pada praktek menuju ke teori dan praktek, dari produk menuju ke proses dan produk, dan akhirnya melalui perjalanan evolusionernya saat ini teknologi pembelajaran islamtelah menjadi sebuah bidang kajian, program studi dan profesi.
Teknologi pembelajaran islam baik sebagai disiplin ilmu, program studi maupun profesi terus mengalami perkembangan yang pesat. Perkembangan teknologi pembelajaran islamyang pesat ini dengan mengambil empat ciri utama, yaitu: 1) menerapkan pendekatan sistem, 2) menggunakan sumber belajar seluas mungkin, 3) bertujuan meningkatkan kualitas belajar manusia, dan 4) berorientasi pada kegiatan instruksional individual $^{15}$. Dengan indikator ini teknologi pembelajaran islamsemakin memperhalus dan mempertajam kemampuannya dalam memecahkan masalah belajar dan pembelajaran. Perkembangan ini pada gilirannya merangsang dan memperkuat perkembangan profesi dalam bidang teknologi pembelajaran.

Teknologi pembelajaran islam sebagai suatu profesi berakar dari penelitian, teori, dan praktek. Suatu profesi harus mempunyai landasan pengetahuan yang menunjang praktek. Tiap kawasan teknologi pembelajaran islam mengandung kerangka pengetahuan yang didasarkan pada hasil penelitian dan pengalaman. Hubungan antara teori dan praktek semakin mantap dengan matangnya bidang garapan. Teori terdiri dari konsep, bangunan (konstruk), prinsip, dan proposisi yang memberi sumbangan terhadap khasanah pengetahuan. Sedangkan praktek merupakan penerapan pengetahuan tersebut dalam memecahkan permasalahan. Dalam teknologi pembelajaran islam baik teori maupun praktek, banyak menggunakan model. Model prosedural, yang menguraikan cara pelaksanaan tugas membantu menghubungkan teori dan praktek. Teori juga dapat menghasilkan model untuk memvisualisasikan hubungan; model ini disebut model konseptual ${ }^{16}$.

Sejalan dengan perkembangan dan kemajuan ilmu pengetahuan dan teknologi yang demikian pesat, khususnya dalam bidang pendidikan, psikologi dan Teknologi Informasi dan Komunikasi (TIK) maka tidak

15 Suparman, M. Atwi (2004), "Desain Instruksional", (Jakarta: Pusat Penerbitan universitas Terbuka), hal. 30-31.

${ }^{16}$ Lihat Seels \& Richey hal. 10-12. 
mustahil ke depannya teknologi pembelajaran islamakan semakin terus berkembang dan memperkokoh diri menjadi suatu disiplin ilmu, program studi, dan profesi yang dapat berperan dalam memecahkan masalah-masalah pembelajaran.

Kendati demikian, harus diakui bahwa perkembangan bidang dan profesi teknologi pembelajaran islamdi Indonesia hingga saat ini boleh dikatakan belum optimal, baik dalam hal desain, pengembangan, pemanfaatan, pengelolaan, maupun evaluasinya. Kiranya masih dibutuhkan usaha perjuangan yang sungguh-sungguh dari semua pihak yang terkait dengan teknologi pembelajaran, baik dari kalangan akademisi, peneliti maupun praktisi.

Dengan demikian konsekwensinya Sumber Daya Manusia (SDM) yang mengelola pendidikan harus memiliki kemampuan akademis dan profesional yang handal untuk mengembangkan dan/atau mengaplikasikan teknologi pendidikan islamagar penyelenggaraan pendidikan menjadi lebih berkualitas, efektif, efisien, dan relevan dengan kebutuhan dan tuntutan zaman.

Manusia agar dapat memenuhi kebutuhannya dengan baik perlu belajar. Sedangkan untuk dapat belajar secara efektif dan efisien perlu memanfaatkan beraneka sumber belajar. Teknologi pembelajaran islam berupaya untuk merancang, mengembangkan dan memanfaatkan aneka sumber belajar sehingga dapat memudahkan atau memfasilitasi seseorang untuk belajar. Pada gilirannya terbukanya kesempatan seseorang untuk belajar sepanjang hayat, di mana saja, kapan saja dan oleh siapa saja, dengan cara dan sumber belajar apa saja yang sesuai dengan kondisi dan kebutuhannya.

Dengan demikian teknologi pendidikan islamislam diperlukan untuk dapat menjangkau peserta didik di manapun mereka berada. Selain itu untuk melayani sejumlah besar dari mereka yang belum memperoleh kesempatan untuk belajar, memenuhi kebutuhan belajar untuk dapat mengikuti perkembangan, dan meningkatkan efisiensi, efektifitas dalam belajar.

Teknologi pendidikan islamsecara konseptual dapat berperan untuk membelajarkan manusia dengan mengembangkan dan atau menggunakan aneka sumber belajar, yang meliputi sumber daya manusia, sumber daya alam dan lingkungan, sumber daya peluang atau kesempatan, serta dengan meningkatkan efektifitas dan efisiensi sumber daya pendidikan ${ }^{17}$.

Berkaitan dengan peranan teknologi pendidikan islamini menurut teknologi pendidikan islammempunyai potensi untuk meningkatkan produktifitas pendidikan, dengan jalan: 1) mempercepat tahap belajar (rate of learning), 2) membantu guru untuk menggunakan waktunya secara lebih baik, 3) mengurangi beban guru dalam menyajikan informasi, sehingga guru dapat membina dan mengembangkan kegairahan belajar peserta $\operatorname{didik}^{18}$.

Dengan demikian teknologi pembelajaran islamberperan dalam upaya pemecahan masalah pendidikan dan pembelajaran dengan cara: 1) memadukan berbagai macam pendekatan dari bidang ekonomi, manajemen, psikologi, rekayasa, dan lainlain secara bersistem; 2) memecahkan masalah belajar pada manusia secara menyeluruh dan serempak, dengan memperhatikan dan mengkaji semua kondisi dan saling kaitan di antaranya; 3) menggunakan teknologi sebagai proses dan produk untuk membantu memecahkan masalah belajar; 4) timbulnya daya lipat atau efek sinegi, dimana penggabungan pendekatan dan atau unsur-unsur mempunyai nilai lebih dari sekedar penjumlahan ${ }^{19}$. Demikian pula pemecahan secara menyeluruh dan serempak akan mempunyai nilai lebih daripada memecahkan masalah secara terpisah.

Fasilitas yang diperlukan pada awal

17 Miarso, Yusufhadi (2004), "Menyemai Benih Teknologi Pendidikan", (Jakarta: Penerbit Prenada Media), hal. 701.

${ }^{18}$ Ibid hal. 109

${ }^{19}$ Ibid hal.78 
pertumbuhan, juga difasilitasikan oleh pemerintah dengan bantuan teknis dari UNICEF, UNISCO, USAID, dan Pemerintah Australia dan Jepang me-lalui the Colombo Plan. Fasilitas ini ter-sebar di beberapa perguruan tinggi (IKIP Jakarta, Bandung, Yogyakarta, Semarang, dan Malang, IPB, ITB, UNDIP, dan ITS), dan berbagai unit pelaksana teknis di pusat maupun daerah. Sekarang ini fasilitas harus diusahakan sendiri secara swadaya.Sebagai suatu disiplin, teknologi pembelajaran islamberpeg angan pada falsafah berkembangnya potensi optimal pembelajar (learners) secara efektif dan efesien serta selaras dengan perkembangan dan kondisi masyarakat dan lingkungan. Sedangkan visinya sebagai disiplin adalah terwujudnya berbagai pola pendidikan dan pembel-ajaran dengan dikembangkannya dan dimanfaatkannya aneka sumber, proses, dan sistem, sesuai dengan kondisi dan kebutuhan. $^{20}$

Peranan teknologi pendidikan islamdalam memecahkan masalah pendidika dan pembelajaran, khususnya dalam perluasan akses dan peningkatan mutu pendidikan, melalui: a) penerapan prosedur pengembangan pembelajaran dalam penyusuanan Kurikulum Tingkat Satuan Pendidikan (KTSP), struktur dan muatan kurikulum, kalender pendidikan, silabus dan perangkat pembelajaran lain, seperti Rencana Pelaksanaan Pembelajaran (RPP); b) penerapan prosedur pengembangan pembelajaran dalam penyusuanan bahan belajar, modul, buku teks, atau buku elektronik (e-book); c) penerapan metode pembelajaran yang lebih menekankan kepada penerapan teori-teori belajar mutakhir, seperti teori belajar konstruktivisme dan paradigma baru pendidikan lainnya; d) mengembangkan dan memanfaatkan berbagai jenis media yang sesuai dengan kebutuhan dan dengan

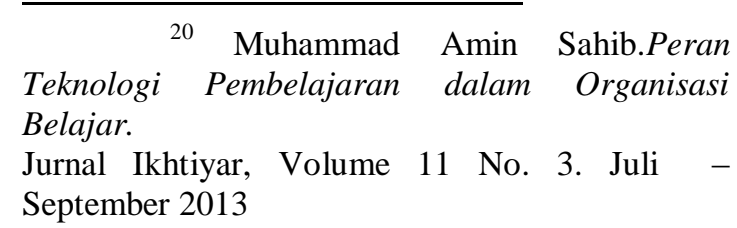

mengindahkan

prinsip-prinsip pemanfaatannya secara efektif dan efisien ${ }^{21}$. dan (e) mengembangkan strategi pembelajaran untuk membangun dan menemukan jati diri melalui proses pembelajaran yang aktif, interaktif, kreatif, efektif dan menyenangkan (PAKEM).

\section{KESIMPULAN}

Teknologi pendidikan islammemiliki peran untuk merancang, mengembangkan dan memanfaatkan aneka sumber belajar sehingga dapat memudahkan atau memfasilitasi seseorang untuk belajar di mana saja, kapan saja dan oleh siapa saja, dengan cara dan sumber belajar apa saja yang sesuai dengan kondisi dan kebutuhannya. Teknologi pembelajaran islammempunyai dua bidang kajian utama, yaitu: a). mengkaji tentang teori belajar dan perilaku manusia lainnya (soft technology), dan b). mengkaji teknologi terapan yang diaplikasikan untuk memecahkan masalah pembelajaran (hard technology). Namun, fokus dari teknologi pembelajaran islambukan pada proses psikologis bagaimana peserta didik belajar, melainkan pada proses bagaimana teknologi perangkat lunak dan keras digunakan mengkomunikasikan pengetahuan, keterampilan, atau sikap kepada peserta didik sehingga peserta didik mengalami perubahan perilaku.Ada lima domain atau bidang garapan teknologi pembelajaran islamatau teknologi instruksional, yaitu desain, pengembangan, pemanfaatan, pengelolaan dan penilaian. Teknologi pembelajaran islamdalam organisasi belajar sebagai suatu organisasi yang belajar secara kolektif dan bersemangat, dan terus menerus mentransformasikan dirinya pada peng-umpulan, pengelolaan dan penggunaan pengetahuan yang lebih baik bagi ke-berhasilan organisasi.

21 Purwanto, dkk (2005), “Jejak Langkah Perkembangan Teknologi Pendidikan di Indonesia", (Jakarta: Pustekkom-Depdiknas), hal. 18. 


\section{DAFTAR PUSTAKA}

[1] Anglin, Gary J. (1995), Instructional Technology, Past, Present, and Future, Second Edition, (Englewood-Corolado. Libraries unlimited, INC).

[2] Finn, J. D. (1960). Technology and the instructional process, Audiovisual Communication Review, 8(1), 9-10.

[3] Hackbarth, Steven, (1996), The Educational Technology Handbook, A Comprehensive Guide: Process and Product for Learning, (Englewood Cliffs: Educational Technology Publications),

[4] Miarso, Yusufhadi (2004), "Menyemai Benih Teknologi Pendidikan", (Jakarta: Penerbit Prenada Media).

[5] Purwanto, dkk (2005), “Jejak Langkah Perkembangan Teknologi pendidikan islamdi Indonesia", (Jakarta: PustekkomDepdiknas).

[6] Sahib Amin. 2013. Peran Teknologi pembelajaran islamdalam Organisasi Belajar.

[7] Jurnal Ikhtiyar, Volume 11 No. 3. Juli - September.
[8] Seels, Barbara B. \& Richey, Rita C., (2000), Instructional technology, The definition and domains of the field, Terjemahan Dewi $S$ Prawiradilaga, $R$. Rahardjo, Yusufhadi Miarso, (Jakarta: Penerbit IPTPI \& LPTK).

[9] Smaldino, S.E.,Russell, J., Heinich, R., \& Molenda, M., (2004). Instructional technology and media for learning. ( $8^{\text {th }}$ ed.). (Englewood Cliffs, N.J.: Prentice Hall).

[10] Suparman, M. Atwi (2004), "Desain Instruksional", (Jakarta: Pusat Penerbitan universitas Terbuka)

[11] Suparman, M. Atwi \& Zuhairi, Aminudin (2004), "Pendidikan Jarak Jauh Teori dan Praktek", (Jakarta: Pusat Penerbitan universitas Terbuka) 